\title{
INVESTIGATION OF PORTEVIN-LE CHATELIER EFFECT OF HOT-ROLLED Fe-13Mn-0.2C-1Al-1Si TWIP STEEL
}

\author{
PREISKAVA PORTEVIN-LE CHATELIER UČINKA PRI VROČEM \\ VALJANJU Fe-13Mn-0.2C-1Al-1Si TWIP JEKLA
}

\author{
Bulent Aydemir ${ }^{1}$, Havva Kazdal Zeytin ${ }^{2}$, Gokhan Guven ${ }^{2}$ \\ ${ }^{1}$ Tubitak National Metrology Institute (UME), P.K. 54, Gebze, Kocaeli 41470, Turkey \\ ${ }^{2}$ Tubitak MRC, Materials Institute, P.K. 21, Gebze, Kocaeli 41470, Turkey \\ bulent.aydemir@tubitak.gov.tr \\ Prejem rokopisa - received: 2015-02-07; sprejem za objavo - accepted for publication: 2015-07-08
}

doi: $10.17222 /$ mit.2015.034

\begin{abstract}
This study was undertaken to investigate the microstructure and mechanical properties of hot rolled Fe-13Mn-0.2C-1Al-1Si TWIP steel. Tensile tests were carried out at different strain rates to determine the Portevin-Le Chatelier (PLC) effect during deformation. Subsequently, the samples were investigated by light microscopy and SEM. The sample microstructures revealed inhomogeneous dislocation zones, deformation twinning and twin-dislocation interactions. Consequently, the PLC effect during deformation was determined to be responsible for the excellent mechanical properties of the TWIP steel.

Keywords: TWIP steel, mechanical properties, microstructure, Portevin Le Chatelier effect

V študiji je bila preiskovana mikrostruktura in mehanske lastnosti vroče valjanega Fe-13Mn-0.2C-1Al-1Si TWIP jekla. Natezni preizkusi so bili izvedeni pri različnih hitrostih obremenjevanja. Kot rezultat nateznega preizkusa je bil ugotovljen učinek Portevin-Le Chatelier (PLC) med deformacijo. Vzorci so bili nato preiskani s svetlobnim mikroskopom in s SEM. Mikrostruktura vzorcev kaže nehomogena področja dislokacij, deformacijske dvojčke in interakcije dvojčkov z dislokacijami. Ugotovljeno je, da so odlične mehanske lastnosti TWIP jekla posledica vpliva PLC med deformacijo.

Ključne besede: TWIP jeklo, mehanske lastnosti, mikrostruktura, vpliv Portevin Le Chatelier
\end{abstract}

\section{INTRODUCTION}

Higher automotive safety standards have led to a strong interest in advanced high strength steel and "super tough", high manganese steel characterized by Twinning-Induced Plasticity (TWIP). The high-manganese austenitic TWIP steels present excellent properties, combining a very large strain-hardening rate and ductility. The TWIP effect is responsible for the observed high maximum stress $(600 \mathrm{MPa}-1100 \mathrm{MPa})$ and good elongation $(50 \%-95 \%) .{ }^{1,2}$ Extensive research has already investigated on high Mn TWIP steels with slightly different compositions. For example: Fe18Mn0.6C, Fe22Mn0.6C, Fe-17Mn-0.6C, Fe-17Mn-0.8C etc. ${ }^{1-9}$

TWIP steels have a high manganese $(\mathrm{Mn})$ content. Manganese tends to stabilize austenite, although its role in the TWIP microstructure is still a subject of active research. Twinning promotes retention of the austenitic microstructure but competes with dislocation glide by impeding dislocation motion at twin boundaries and other dislocation-dislocation interactions (e.g. forest hardening). Twin formation is associated with Stacking Fault Energy (SFE) at room temperature. Deformation twinning in low SFE austenitic steels leads to high strain-hardening and improved ductility of TWIP steel. In low SFE austenitic steels, the increased partial dislocation separation results in ease of twin nucleation. With applied deformation, the grains are progressively subdivided by the twinning process, and the internal twin boundaries increase the strain hardening. Though the actual twinning strain is limited, and the twin formation itself may actually cause softening, the twin boundaries decrease the dislocation slip distances progressively and promote dislocation accumulation and storage, especially at grain boundaries. ${ }^{1}$ This dynamic Hall-Petch effect may not be the only cause for the observed strain hardening of TWIP steel. In fact, the mechanism leading to high strain hardening in TWIP steel is still a matter of debate.

Austenitic steels usually reveal dynamic strain aging (DSA); a form of unstable plastic flow found in the dilute metal alloys. ${ }^{10-13}$ Portevin-Le Chatelier bands (or the PLC effect) and serrated flow curves are usual manifestations of DSA, which occurs over a large temperature range. ${ }^{14}$ The bands, which are regions of localized plasticity, are commonly divided in three groups. As: Type A (continuously propagates across the gage length of a tensile specimen); Type B (discontinuous propagation or "hop"); and Type C (no spatial correlation). A common explanation of DSA in metals centers on dislocation-solute interactions in which solute atoms diffuse to dislocations temporarily arrested at obstacles (or trapped by the local energy landscape in the lattice) thereby increasing the stress required to release the dislocations. ${ }^{10}$ With aging, the dislocations are suddenly released, and 
the process repeats elsewhere. There have been many publications on dynamic strain aging and the PLC effect in TWIP steels. ${ }^{15-17}$ The microstructure and mechanical properties of the hot rolled Fe-13Mn-0.2C-1Al-1Si TWIP Steel is investigated in this study. The conclusion of the study was expected to be an aid for future industrial manufacture of TWIP steel.

\section{MATERIAL AND EXPERIMENTAL PROCEDURE}

The chemical composition of the newly developed Fe-13Mn-0.2C-1Al-1Si TWIP steel is given in Table 1. The TWIP steel was melted by induction melting under an inert gas atmosphere in a furnace. Then, it was cast in a ceramic mold with a thickness of about $20 \mathrm{~mm}$. The ingot was homogenized at $1200{ }^{\circ} \mathrm{C}$ for $6 \mathrm{~h}$ and then hot-rolled to a thickness of $5 \mathrm{~mm}$ i.e. a total deformation of $75 \%$ by thickness. In addition, no annealing was carried out.

Table 1: Chemical composition of investigated alloy in mass fractions, $(w / \%)$

Tabela 1: Kemijska sestava preiskovane zlitine, v masnih odstotkih $(w / \%)$

\begin{tabular}{|c|c|c|c|c|c|}
\hline $\mathrm{C}$ & $\mathrm{Mn}$ & $\mathrm{Si}$ & $\mathrm{Cr}$ & $\mathrm{N}$ & $\mathrm{Al}$ \\
\hline 0.23 & 12.73 & 1.08 & 0.12 & 0.10 & 0.95 \\
\hline
\end{tabular}

The tensile samples were prepared mechanically in accordance with the EN ISO 6892 Standard. ${ }^{18}$ The experiments were conducted with a Zwick Z250 tensile tester at the Material Institute in TUBITAK. The force

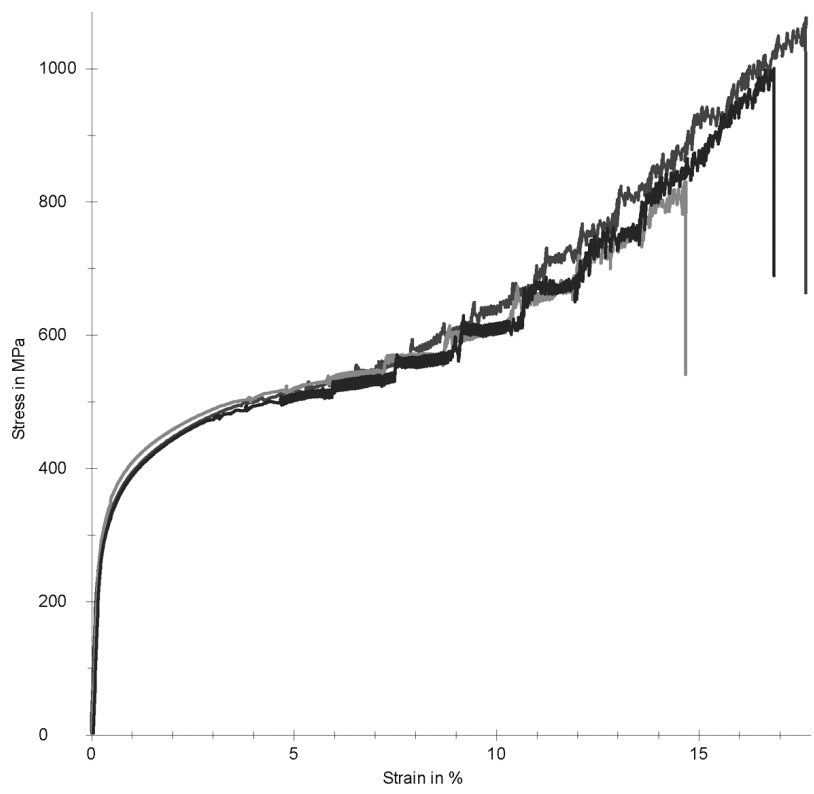

Figure 1: Stress-strain curves of Fe-13Mn-0.2C-1Al-1Si TWIP steel at different test speeds at room temperature $(2 \mathrm{~mm} / \mathrm{min}, 5 \mathrm{~mm} / \mathrm{min}, 10$ $\mathrm{mm} / \mathrm{min}$ )

Slika 1: Krivulje napetost-raztezek Fe-13Mn-0.2C-1Al-1Si TWIP jeklo pri različnih hitrostih preizkusa, pri sobni temperaturi $(2 \mathrm{~mm} / \mathrm{min}$, $5 \mathrm{~mm} / \mathrm{min}, 10 \mathrm{~mm} / \mathrm{min}$ ) accuracy class of the machine was "class 0.5 " according to EN ISO 7500-1 standard. ${ }^{19}$ The extensometer was used together with a strain measurement system. The extensometer accuracy class of the machine was "class $0.5^{\prime \prime}$ according to EN ISO 9513 standard..$^{20}$ All tests were performed at $23 \pm 1{ }^{\circ} \mathrm{C}$ and $50 \pm 10 \%$ humidity. The specimen was gripped by jaws and preload applied. Then, the extensometer was automatically attached to the specimen. The gage length of the applied extensometer was $50 \mathrm{~mm}$. The tensile test was carried out with test speeds of $(2,5$ and 10$) \mathrm{mm} / \mathrm{min}$. In addition, the Charpy impact energy of 3 samples was tested at room temperature by Charpy V-notch measurements on $55 \mathrm{~mm} \times$ $10 \mathrm{~mm} \times 5 \mathrm{~mm}$ specimens.

The samples' microstructures were examined by light (Nikon) and scanning electron microscopes (SEM-JeolJSM 6335F-Japan). The samples for microstructure investigations were cut suitably and mounted, mechanically polished, and etched using a nital solution.

\section{RESULTS AND DISCUSSION}

Figure 1 shows a typical room temperature stress-strain curve of the Fe-13Mn-0.2C-1Al-1Si TWIP steel at different test speeds. Mechanical property values obtained from the data in Figure 1 are listed in Table 2. Average Charpy impact energy values in Joules are given in Table 2. Figure 2 presents the tensile true stress-true strain curves at different test speeds.

There isn't a yield point nor a yield plateau observed on the stress-strain curve, though some remarkable serrated flows are found at strains above $5 \%$. As can be seen the steel retains high strength and elongation without necking at these strain rates. The main differences between the stress-strain curves are the morphologies of

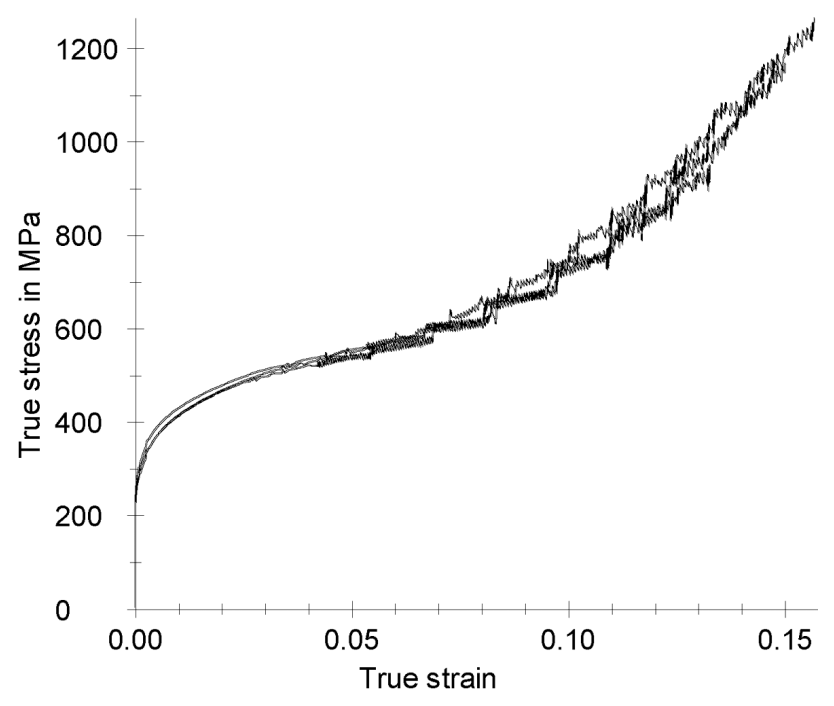

Figure 2: True stress-true strain curves of Fe-13Mn-0.2C-1Al-1Si TWIP steel at different test speeds at room temperature

Slika 2: Prava krivulja napetost-raztezek TWIP jekla Fe-13Mn-0.2C-1 $\mathrm{Al}-1 \mathrm{Si}$ pri različnih hitrostih preizkusa na sobni temperaturi 


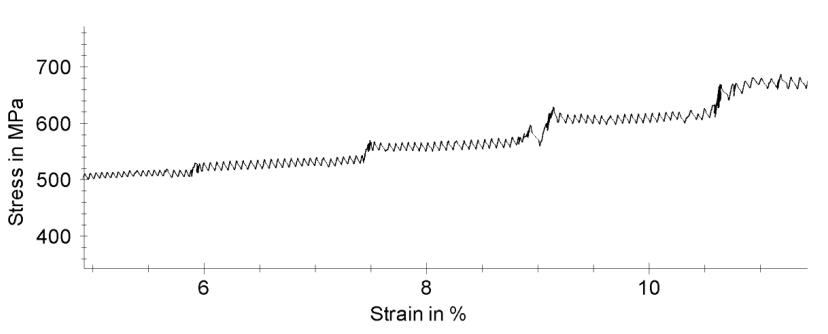

Figure 3: The room-temperature tensile response (magnified) of Fe-13Mn-0.2C-1Al-1Si TWIP steel at $10 \mathrm{~mm} / \mathrm{min}$ test speed

Slika 3: Povečan odziv pri nateznem preiskusu Fe-13Mn-0.2C1Al-1Si TWIP jekla pri hitrosti preizkusa $10 \mathrm{~mm} / \mathrm{min}$ na sobni temperaturi

the serrations. The fluctuations on the stress-strain curve result from the dynamic strain aging (DSA) which is consistent with earlier work on cold-rolled TWIP steel. $^{21-23}$

Table 2: Mechanical properties of Fe-13Mn-0.2C-1Al-1Si TWIP steel at room temperature

Tabela 2: Mehanske lastnosti Fe-13Mn-0.2C-1Al-1Si TWIP jekla pri sobni temperaturi

\begin{tabular}{|c|c|c|c|c|}
\hline Test speed & $R_{\mathrm{p}} 0.2$ & $R_{\mathrm{m}}$ & A & $E_{\text {impact }}$ \\
\hline$(\mathrm{mm} / \mathrm{min})$ & $(\mathrm{MPa})$ & $(\mathrm{Mpa})$ & $(\%)$ & $(\mathrm{J})$ \\
\hline 10 & 308 & 1075 & 17 & \multirow{2}{*}{23,9} \\
\cline { 1 - 4 } 5 & 307 & 844 & 14 & \\
\hline 2 & 306 & 999 & 16 & \\
\hline
\end{tabular}
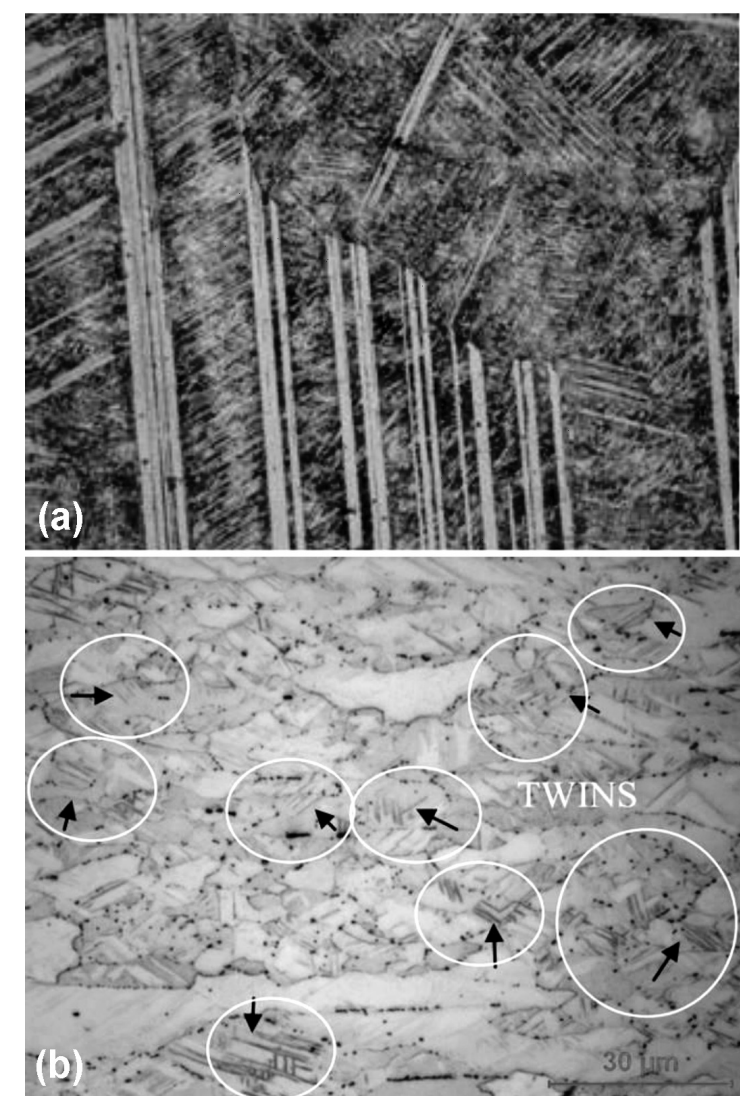

Figure 4: Microstructure of the TWIP steel: a) as cast, b) hot rolled Slika 4: Mikrostruktura TWIP jekla: a) lito, b) vroče valjano

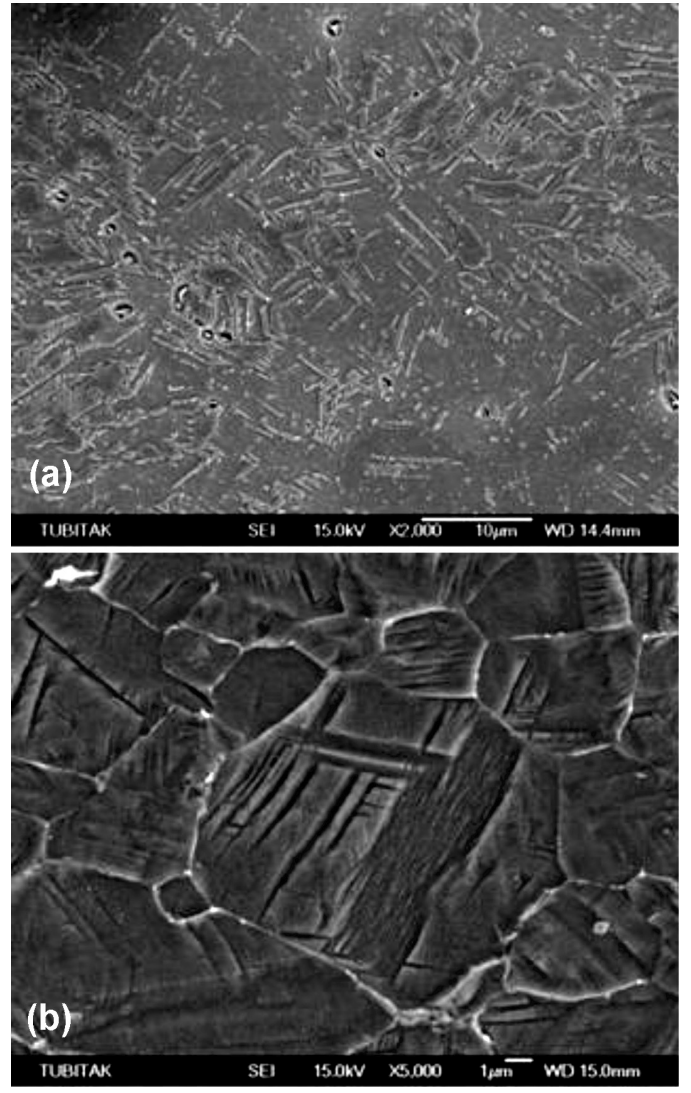

Figure 5: Microstructure of the TWIP steel (SEM): a) 2000x, b) 5000× Slika 5: Mikrostruktura TWIP jekla $($ SEM): a) $2000 \times$, b) $5000 \times$

Evidence of the appearance of deformation bands and the coherent evolution of the serration is seen at room temperature. In Figure $\mathbf{3}$ the magnified stress-strain curve at $10 \mathrm{~mm} / \mathrm{min}$ test speed is shown. The stressstrain curve shows clear stress jumps and dips of the same type described by K. Renard et al. ${ }^{17}$ The observed serrations correspond to those of type A i.e. the bands propagate continuously after nucleation.

An image of the hot rolled Fe-13Mn-0.2C-1Al-1Si TWIP Steel obtained with a Nikon L150 light microscope is given in Figure 4. The microstructure shows

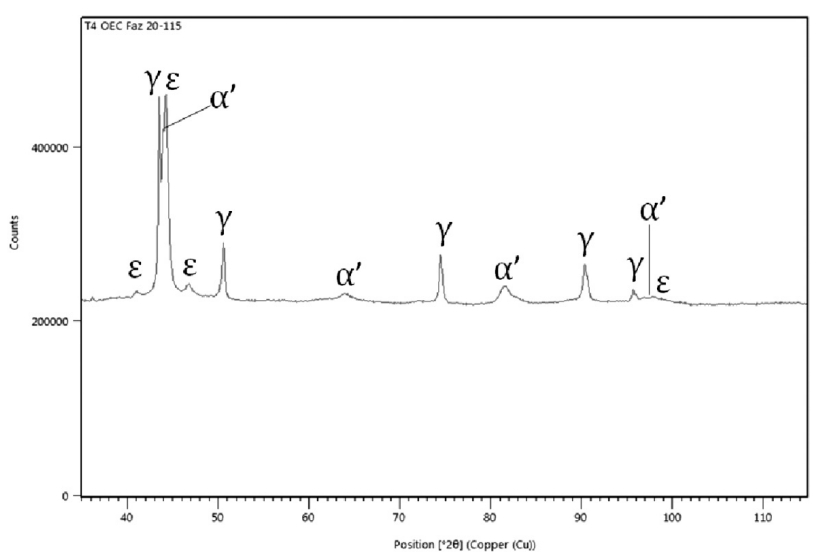

Figure 6: Diffraction pattern of the TWIP steel Slika 6: Rentgenogram vzorca TWIP jekla 
austenite grains containing a secondary precipitate phase. The precipitates are mostly observed at grain boundaries. Hot-rolling of the TWIP steel resulted in annealing of the austenite grain twins, presenting as mechanical twins. Deformation twins and twin-dislocation interactions are observed in the deformed TWIP steel. This twinning produces high strain hardening and
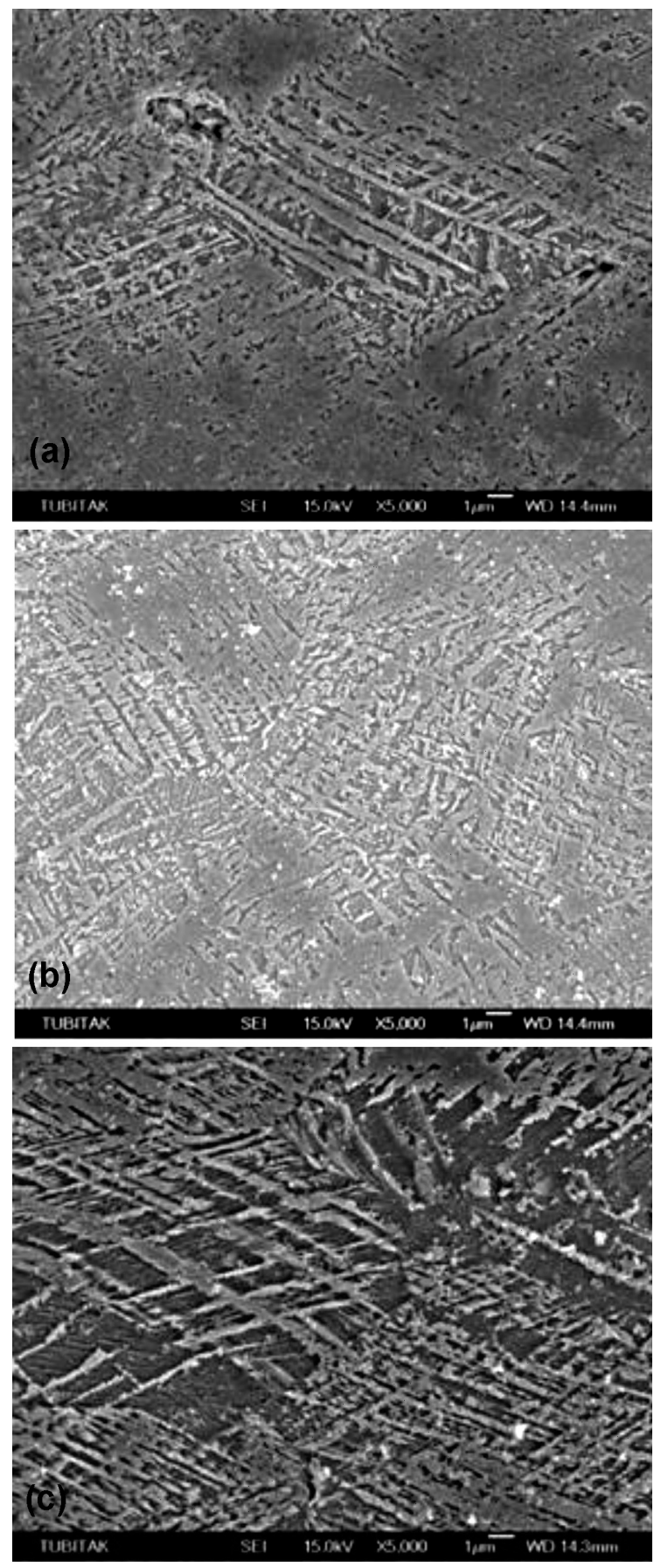

Figure 7: Microstructure of the TWIP steel necked region after applying the tensile test at different speeds: a) $2 \mathrm{~mm} / \mathrm{min}$, b) 5 $\mathrm{mm} / \mathrm{min}$, c) $10 \mathrm{~mm} / \mathrm{min}$

Slika 7: Mikrostruktura področja vratu pri TWIP jeklu, po nateznem preizkusu pri različnih hitrostih preizkusa: a) $2 \mathrm{~mm} / \mathrm{min}$, b) $5 \mathrm{~mm} / \mathrm{min}$, c) $10 \mathrm{~mm} / \mathrm{min}$ higher ductility, and is responsible for the excellent mechanical properties of the hot-rolled TWIP steel.

SEM images of this sample are shown in Figure 5. Analysis of secondary precipitated phases observed at the grain boundaries yields $\varepsilon$ and $\alpha^{\prime}$ particles. A secondary phase precipitated within austenite matrix is also seen. The $\varepsilon$ and $\alpha$ ' martensite transformations occurred
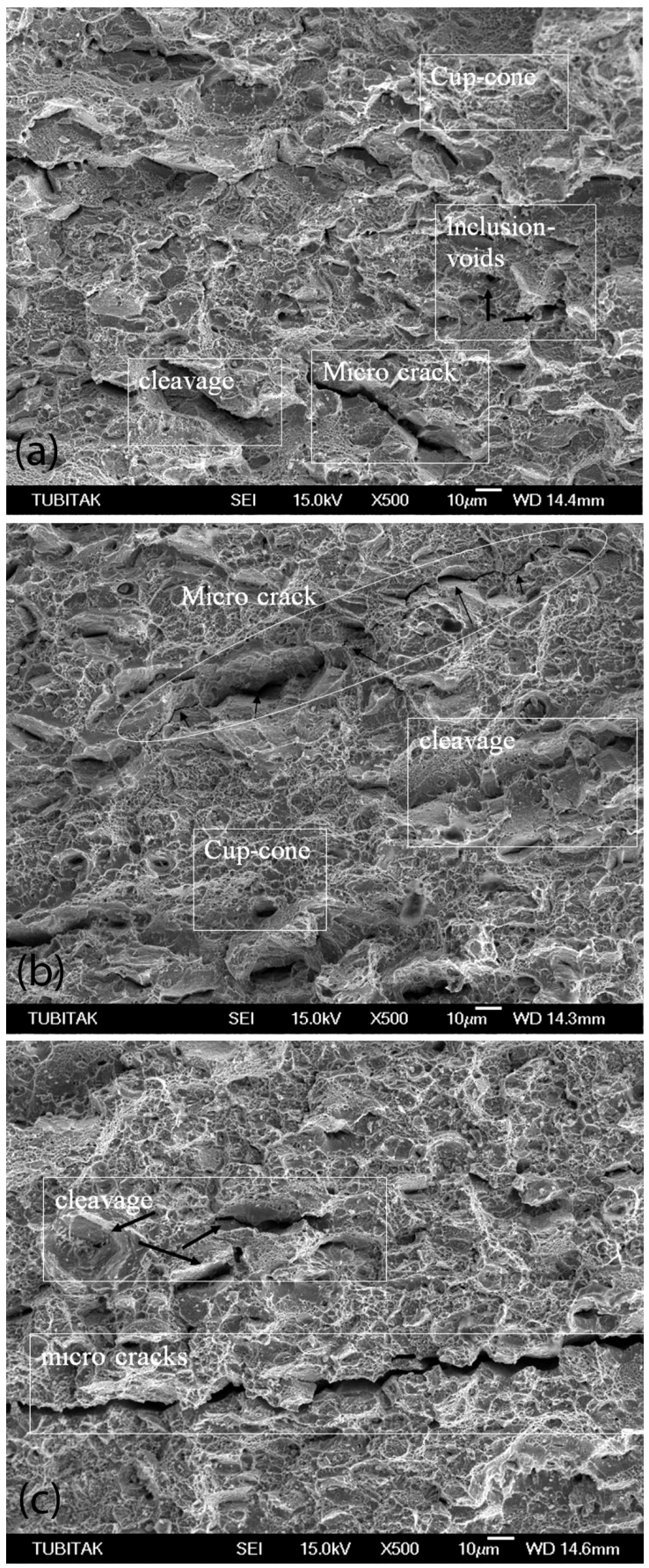

Figure 8: Microstructure of the TWIP steel necked region after applying the tensile test with test speed: a) $2 \mathrm{~mm} / \mathrm{min}$, b) $5 \mathrm{~mm} / \mathrm{min}$, c) $10 \mathrm{~mm} / \mathrm{min}$

Slika 8: Mikrostruktura področja vratu pri TWIP jeklu po nateznem preizkusu s hitrostjo preizkusa: a) $2 \mathrm{~mm} / \mathrm{min}$, b) $5 \mathrm{~mm} / \mathrm{min}$, c) 10 $\mathrm{mm} / \mathrm{min}$ 
after hot rolling. In the present work, the steel is cooled in air after being hot rolled. Large parallel laths crossing the micrograph correspond to $\varepsilon$ martensite, with $\alpha$ ' martensite also forming. With a relatively low stability, the austenite transformation proceeds by $\gamma \rightarrow \varepsilon \rightarrow \alpha$, martensitic transformations, resulting in a high workhardening rate. Stability against the $\gamma \rightarrow \varepsilon$ martensite transformation is usually considered to imply stability against the $\gamma \rightarrow \alpha^{\prime}$ martensite transformation since $\varepsilon$ martensite laths form as an intermediate phase. ${ }^{8,24}$ The Diffraction Pattern is given in Figure 6.

I. Gutierrez-Urrutia and D. Raabe ${ }^{25}$ in their study of FeMnAlC steels, and many other researchers, reported a form of carbides at the grain boundaries in the sediments, the k-carbides (Fe, Mn) $)_{3} \mathrm{AlC} .{ }^{24,25} \mathrm{SEM}$ images of the second phase are precipitated in the grain boundary $(\mathrm{Fe}, \mathrm{Mn})_{3} \mathrm{AlC}$ phase. This phase is reported in the austenite grain boundaries of FeMnAl steel with high carbon content after hot-rolling, and is deposited after an aging process. Optical microscopy, SEM, and XRD studies show the k-carbides to be precipitated in the austenite grain boundary phase.

The microstructures of this TWIP steel at the necked region in parallel with the tension force direction after applying the tensile test with $(2,5$, and 10$) \mathrm{mm} / \mathrm{min}$ test speed were analyzed. These fracture surface images are shown in Figures $\mathbf{7}$ and $\mathbf{8}$. The cleavage regions in the fracture surface images increased with test speed increases, and there was a growth of cracks. SEM photos clearly demonstrate the typical ductile pattern of surface fracture. Cleavage fracture areas and micro-cracks in the grain developed when the test speed increases. Unfilled areas formed by pouring of inclusions can be observed on the fracture surface.

Figure 8 shows a local deformation region with many parallel deformation twins. Moreover, the high dislocation density found in the micro-scale mechanical twins, indicate that the twin boundaries could play a similar role to grain boundaries as short range obstacles for gliding dislocations and strongly delay the necking of the sample. Thus the samples in this study showed high strength and moderate elongation.

This evolution of the serrations with the strain level is the commonly expected behavior in a classical PLC scheme. This reflects an increase of DSA effectiveness due to a rise in the dislocation density when the strain increases. The evolution of the serration type with strain rate is also a characteristic of DSA. Indeed, when the strain rate decreases, that is, the waiting time of the dislocations increases, the magnitude of the serrations was enhanced. As a consequence, the jerky flow was mostly of type A when the test speed was sufficiently large, as was the case at $10 \mathrm{~mm} / \mathrm{min}$. Finally, DSA should be avoided in sheets during manufacturing as it gives rise to non-homogeneous plastic flow during sheet forming processes and may lead to surface defects on formed parts.

\section{CONCLUSIONS}

This study investigated the microstructure and mechanical properties of hot rolled Fe-13Mn-0.2C-1Al-1Si TWIP steel. The conclusions are summarized in the following:

a) The hot-rolled Fe-13Mn-0.2C-1Al-1Si TWIP steel exhibited excellent mechanical properties with an ultimate strength of $1075 \mathrm{MPa}$ and an elongation of $17 \%$.

b) Many deformation twins and twin-dislocation interactions were observed in the deformed TWIP steel microstructure. This is due to the influence of the PLC effect. The PLC effect during deformation was determined to be responsible for the excellent mechanical properties of the hot-rolled TWIP steel.

c) From a technological point of view the PLC effect, and hence DSA, must be avoided. DSA gives rise to non-homogeneous plastic flow during sheet forming processes and may lead to surface defects on formed parts.

\section{REFERENCES}

${ }^{1}$ S. Allain, J. P. Chateau-Cornu, O. Bouaziz, A physical model of the twinning-induced plasticity effect in a high manganese austenitic steel, Mater. Sci. Eng. A, 387-389 (2004), 143, doi:10.1016/ j.msea.2004.01.060

${ }^{2}$ L. Chen, H. S. Kim, S. K. Kim, B. C. De Cooman, On the Transition of Internal to External Selective Oxidation on CMnSi TRIP, Metallurgical and Materials Transactions A, 47 (2007) 12, 1804-1812, doi:10.2355/isijinternational.47.1804

${ }^{3}$ Y. N. Dastur, W. C. Leslie, Mechanism of work hardening in Hadfield manganese steel, Metal. Trans. A, 12A (1981) 5, 749-759, doi:10.1007/BF02648339

${ }^{4}$ O. Grassel, L. Krüger, G. Frommeyer, L. W. Meyer: Int. J. Plast., Microstructure-deformation relationships in fine grained high manganese TWIP steel-the role of local texture, International Journal of Materials Research, 16 (2000) 10-11, 1391, doi:10.1016/ S0749-6419(00)00015-2

${ }^{5}$ M. Koyama, T. Sawaguchi, T. Lee, C. S. Lee, K. Tsuzaki, Work hardening associated with $\varepsilon$-martensitic transformation deformation twinning and dynamic strain aging in Fe-17Mn-0.6C and $\mathrm{Fe}-17 \mathrm{Mn}-0.8 \mathrm{C}$ TWIP steels, Materials Science and Engineering A, 528 (2011), 7310-7316, doi:10.1016/j.msea.2011.06.011

${ }^{6}$ I. Karaman, H. Sehitoglu, K. Gall, Y. I. Chumlyakov, H. J. Maier, Deformation of single crystal Hadfield steel by twinning and slip, Acta Mater., 48 (2000), 1345, doi:10.1016/S1359-6454(99)00383-3

${ }^{7}$ S. Kibey, J. B. Liu, M. J. Curtis, D. D. Johnson, H. Sehitoglu, Effect of nitrogen on generalized stacking fault energy and stacking fault widths in high nitrogen steels, Acta Mater., 54 (2006), 2991, doi:10.1016/j.actamat.2006.02.048

${ }^{8}$ E. Bayraktar, F. A. Khalid, C. Levaillant: J. Mater., Deformation and fracture behaviour of high manganese austenitic steel, Process. Technol., 147 (2004), 145, doi:10.1016/j.jmatprotec.2003.10.007

${ }^{9}$ B. X. Huang, X. D. Wang, Y. H. Rong, L. Wang, L. Jin, Mechanical behavior and martensitic transformation of an $\mathrm{Fe}-\mathrm{Mn}-\mathrm{Si}-\mathrm{Al}-\mathrm{Nb}$ alloy, Mater.Sci. Eng. A, A438-440 (2006), 306, doi:10.1016/ j.msea.2006.02.150

${ }^{10}$ L. G. Hector, P. D. Zavattieri, Nucleation And Propagation Of Portevin-Le Chatelier Bands In Austenitic Steel With Twinning Induced Plasticity, Proceedings of the SEM Annual Conference, Indianapolis, USA 2010 


\section{B. AYDEMIR et al.: INVESTIGATION OF PORTEVIN-LE CHATELIER EFFECT OF HOT-ROLLED ...}

${ }^{11}$ S. Kumar, E. Pink, Dynamic strain aging in a tungsten heavy metal, Scripta Mat., 35 (1996), 1047-1052, doi:10.1016/1359-6462(96) 00262-X

${ }^{12}$ J. M. Robinson, M. P. Shaw, Microstructural and mechanical influences on dynamic strain aging phenomena, Int. Materials Reviews, 39 (1994), 113-121, doi:10.1179/imr.1994.39.3.113

${ }^{13}$ J. A. Yakes, C. C. Li, W. C. Leslie, The Effect of Dynamic Strain Aging on the Mechanical Properties of Several HSLA Steel, SAE Trans., SAE 790009 (1980), 44-59

${ }^{14}$ B. Skoczen, J. Bielski, S. Sgobba, D. Marcinek, Constitutive Model of Discontinuous Plastic Flow at Cryogenic Temperature, Int. J. Plasticity, (2010), doi:10.1016/j.ijplas.2010.02.003

${ }^{15}$ P. Zavattieri, V. Savic, L. G. Hector Jr., J. R. Fekete, W. Tong, Y. Xuan, Spatio-temporal characteristics of the Portevin-Le Chātelier effect in austenitic steel with twinning induced plasticity, Int. J. Plasticity, 25 (2009), 2298-2330, doi:10.1016/j.ijplas.2009.02.008

${ }^{16}$ B. C. De Cooman, L. Chen, S. Kim, H. S. Estrin, Y. Kim, S. K State-of-the-Science of High Manganese TWIP Steels for Automotive Applications, Springer, \# 2010, 165-183

${ }^{17}$ K. Renard, S. Ryelandt, P. J. Jacques, Characterization of the Portevin-Le Chatelier effect affecting an austenitic TWIP steel based on digital image correlation, Mat. Sci. Eng. A, 527 (2010), 2969-2977, doi:10.1016/j.msea.2010.01.037

${ }^{18}$ EN ISO 6892-1:2009, Metallic materials - Tensile testing -Part 1: Method of test at room temperature

${ }^{19}$ EN ISO 7500-1:2015 Metallic materials - Verification of static uniaxial testing machines - Part 1: Tension/compression testing machines - Verification and calibration of the force-measuring system
${ }^{20}$ EN ISO 9513:2012 Metallic materials - Calibration of extensometer systems used in uniaxial testing

${ }^{21}$ L. Zhang, X. H. Liu, K. Y. Shu, Microstructure and Mechanical Properties of Hot-Rolled Fe-Mn-C-Si TWIP Steel, J. Iron. Steel. Res. Int., 18 (2011) 12, 45-48, 64, doi:10.1016/S1006-706X(12)60008-9

${ }^{22}$ O. Bouaziz, S. Allain, C. Scott, Effect of grain and twin boundaries on the hardening mechanisms of twinning-induced plasticity steels, Scripta Mater., 58 (2008) 6, 484, doi:10.1016/j.scriptamat.2007. 10.050

${ }^{23}$ D. Barbier, N. Gey, S. Allain, N. Bozzolo, M. Humbert, Analysis of the tensile behavior of a TWIP steel based on the texture and microstructure evolutions, Mater. Sci., 500 (2009) 1-2, 196, doi:10.1016/j.msea.2008.09.031

${ }^{24}$ S. S. F., De Dafé, F. L. Sicupira, F. C. S. Matos, N. S. Cruz, D.R Moreira, D.B. Santos, Effect of cooling rate on $\left(\varepsilon, \alpha^{\prime}\right)$ martensite formation in twinning/transformation-induced plasticity $\mathrm{Fe}-17 \mathrm{Mn}$ 0.06C steel, Mat. Res., 16 (2013) 6, 1229-1236, doi:10.1590/S151614392013005000129

${ }^{25}$ I. Gutierrez-Urrutia, D. Raabe, High strength and ductile low density austenitic FeMnAlC steels: Simplex and alloys strengthened by nanoscale ordered carbides, Materials Science and Technology, 30 (2014) 9, 1099, doi:10.1179/1743284714Y.0000000515

${ }^{26}$ Y. Minamino, Y. Koizuma, N. Tsujia, N. Hirohataa, K. Mizuuchib, Y. Ohkandab, Microstructures and mechanical properties of bulk nanocrystalline $\mathrm{Fe}-\mathrm{Al}-\mathrm{C}$ alloys made by mechanically alloying with subsequent spark plasma sintering, Science and Technology of Advanced Materials, (2004) 5, 133-143, doi:10.1016/j.stam.2003. 11.004 